\title{
Extrapulmonary Small Cell Carcinoma of the Seminal Vesicles and Prostate Demonstrated on I8F-FDG Positron Emission Tomography/Computed Tomography
}

\author{
I8F-FDG Pozitron Emisyon Tomografi/Bilgisayarlı Tomografi ile Saptanan Seminal Vezikül ve \\ Prostat Ekstrapulmoner Küçük Hücreli Karsinomu
}

\author{
Amir Iravani Tabrizipour1, Lily Shen1, Robert Mansberg1,2, Bui Chuong1,2 \\ INepean Hospital, Department of Nuclear Medicine and PET, Penrith, Australia \\ 2Sydney University Sydney Medical School, NSW, Australia
}

\begin{abstract}
Extrapulmonary primary small cell carcinomas arising from the urogenital tract is infrequent. It can rarely arise from the prostate and even more rarely from the seminal vesicles. We present a 79-year-old male who was admitted due to acute renal failure with a history of radical radiotherapy for prostate adenocarcinoma 13 years ago. The prostate specific antigen level was not elevated. An abdominopelvic computed tomography (CT) scan showed markedly enlarged seminal vesicles causing bilateral ureteral obstruction and a mildly enlarged prostate. Further evaluation with fluorine-18-fluorodeoxyglucose (18F-FDG) positron emission tomography/CT demonstrated extensive 18F-FDG uptake in the pelvis with diffuse involvement of both seminal vesicles and the prostate without pathologic uptake in the lungs or elsewhere in the body. Core biopsies of the prostate and both seminal vesicles revealed diffuse involvement by small cell carcinoma. Therapy could not be instituted due to a rapid deterioration in the patient's clinical condition.

Keywords: Fluorine-18-fluorodeoxyglucose, positron-emission tomography, small cell carcinoma, seminal vesicles, prostate cancer
\end{abstract}

\section{Öz}

Ürogenital sistem kaynaklı ekstrapulmoner primer küçük hücreli karsinom nadir görülür. Seyrek olarak prostattan daha da nadir olarak seminal veziküllerden kaynaklanabilir. Bu yazıda, 13 yıl önce prostat adenokarsinomu nedeniyle radikal radyoterapi uygulanma öyküsü bulunan ve akut böbrek yetmezliği nedeniyle yatırılan 79 yaşında bir erkek hasta sunulmaktadır. Prostat spesifik antijen değeri yükselmemişti. Abdominopelvik bilgisayarlı tomografide (BT) bilateral üreter obstrüksiyonuna neden olacak şekilde ciddi derecede büyümüş seminal veziküller ve hafif büyümüş prostat bezi saptandı. Fluorodeoksiglukoz F18 (18F-FDG) pozitron emisyon tomografi/BT pelviste her iki seminal vezikül ve prostatta yaygın 18F-FDG tutulumu saptadı, akciğerler ya da diğer vücut bölgelerinde patolojik tutulum saptanmadı. Prostat ve her iki seminal vezikülden yapılan kor biyopsiler yaygın küçük hücreli karsinom ortaya koydu. Hastanın klinik durumunda hızla kötüleşme nedeniyle tedaviye başlanamadı.

Anahtar kelimeler: Fluorodeoksiglukoz F18, pozitron emisyon tomografi, küçük hücreli karsinom, seminal veziküller, prostat kanseri

Address for Correspondence: Robert Mansberg MD, Nepean Hospital, Department of Nuclear Medicine and PET, Penrith, Australia Phone: +61247342156 E-mail: mansberg@usyd.edu.au Received: 21.12.2014 Accepted: 02.03.2015 


\section{Introduction}

Small-cell carcinoma usually originates from the lung and accounts for $18 \%$ of all lung cancers. Nevertheless, the primary site can rarely be outside the lungs and pleural spaces, which are referred to as extrapulmonary smallcell carcinoma (EPSCC) (1). Besides the respiratory tract, small cell carcinoma can rarely arise from the prostate and in extremely rare cases from the seminal vesicles (2). Herein, we present a rare case of EPSCC demonstrated on fluorine-18-fluorodeoxyglucose (18F-FDG) positron emission tomography/computed tomography (PET/CT) with extensive involvement of the seminal vesicles and prostate gland.

\section{Case Report}

A 79 year-old male was admitted with acute renal failure with a history of radical radiotherapy for prostate adenocarcinoma 13 years ago. The prostate specific antigen level was not elevated. The abdominopelvic CT scan showed markedly enlarged seminal vesicles occupying most of the pelvic cavity causing bilateral ureteral obstruction, and loss of fat plane between seminal vesicles and a mildly enlarged prostate gland indicating local invasion of the tumor. 18F-FDG PET/CT demonstrated intense 18F-FDG uptake $\left(S U V_{\text {max }}: 7.2\right)$ throughout the bilateral markedly enlarged seminal vesicles with diffuse involvement of the prostate (Figure 1). There was no primary pulmonary lesion or metastatic spread on either diagnostic CT of the chest or $18 \mathrm{~F}-\mathrm{FDG}$ PET/CT. Percutaneous core biopsies of the prostate and both seminal vesicles revealed diffuse small cell carcinoma (Figure 2). The patient was diagnosed with urogenital EPSCC, however, the origin of the tumor remained unclear. The patient succumbed to the disease prior to commencement of systemic therapy.

\section{Literature Review and Discussion}

Small-cell carcinoma usually originates from the lung and accounts for $18 \%$ of lung cancers, but very rarely the primary site is detected outside the lungs and pleural spaces, which is called EPSCC (1). Small cell carcinoma of the prostate accounts for less than $1 \%$ of all prostate cancers while there are only a few case reports of primary small cell carcinoma of the seminal vesicles (2). Seminal vesicle malignancies are mostly secondary tumors from adjacent organs such as the prostate rather than primary intrinsic tumors (3). Several different routes of invasion have been suggested, most commonly from tumor extension through the ejaculatory ducts or direct spread across the prostatic base (4). Approximately $25-40 \%$ of cases is initially diagnosed as prostatic adenocarcinoma and recurs as small cell carcinoma after initial therapy, and the median interval between diagnosis of prostatic adenocarcinoma and recurrence of small cell carcinoma is reported as 25 months (2). Small cell carcinoma commonly presents with distant metastases in up to $25 \%$ of patients with small cell carcinoma of the prostate, and with locally advanced disease in some cases due to absence of symptoms in early stages (2). The microscopic features of urogenital small cell carcinoma are similar to those seen in other organs and show high grade and poor differentiation (5). The prognosis of urogenital small cell carcinoma is poor with a median survival of less than 1 year (6). Early diagnosis and accurate staging are important since surgery with curative intent may only be considered for localized disease (7).
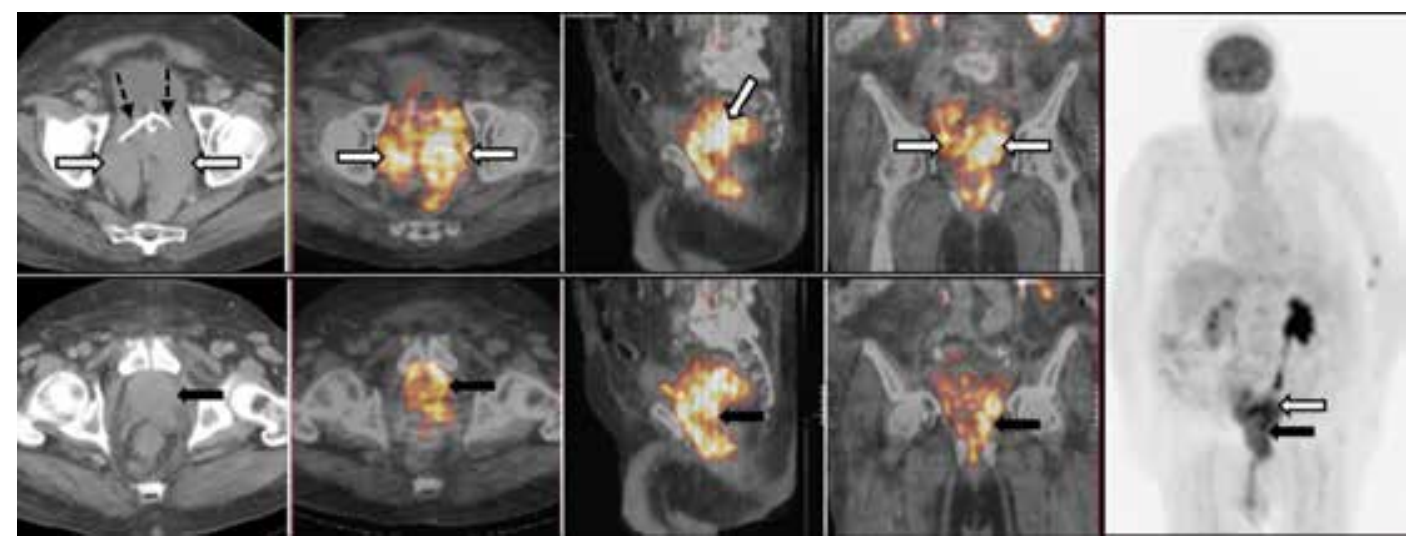

Figure 1. Upper row: Axial pelvic computed tomography demonstrated bilateral markedly enlarged seminal vesicles occupying most of the pelvic cavity, measuring $9 \times 6 \mathrm{~cm}$ on the left and $7 \times 4 \mathrm{~cm}$ on the right (white arrows), causing bilateral ureteral obstruction requiring bilateral ureteral stents (dashed arrows). Fusion fluorine-18-fluorodeoxyglucose (18F-FDG) positron emission tomography/computed tomography (PET/CT) (axial, sagittal and coronal) demonstrated heterogeneous intense 18F-FDG uptake (SUV ${ }_{\max }$ : 7.2) throughout the markedly enlarged seminal vesicles (white arrows). The patient had an indwelling urinary catheter, hence no significant retained urinary tracer activity was seen in the bladder and no obvious abnormal tracer activity was seen in the bladder wall, Lower row: Axial pelvic CT demonstrated mildly enlarged prostate gland. Fusion 18F-FDG PET/CT (axial, sagittal and coronal) demonstrated diffusely increased ${ }^{18 F-F D G ~ u p t a k e ~ i n ~ t h e ~ p r o s t a t e ~ g l a n d ~ w i t h ~ d i r e c t ~ i n v a s i o n ~ o f ~ t h e ~ p e l v i c ~ f l o o r ~ n o t ~ e x c l u d e d ~(b l a c k ~ a r r o w s), ~ A n t e r i o r ~ w h o l e ~ b o d y ~ M I P s ~ i m a g e ~}$ demonstrated no suspicious focal FDG uptake outside the pelvis to suggest a primary lesion elsewhere (including the lungs) or metastatic spread. Low-grade

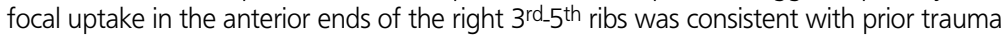




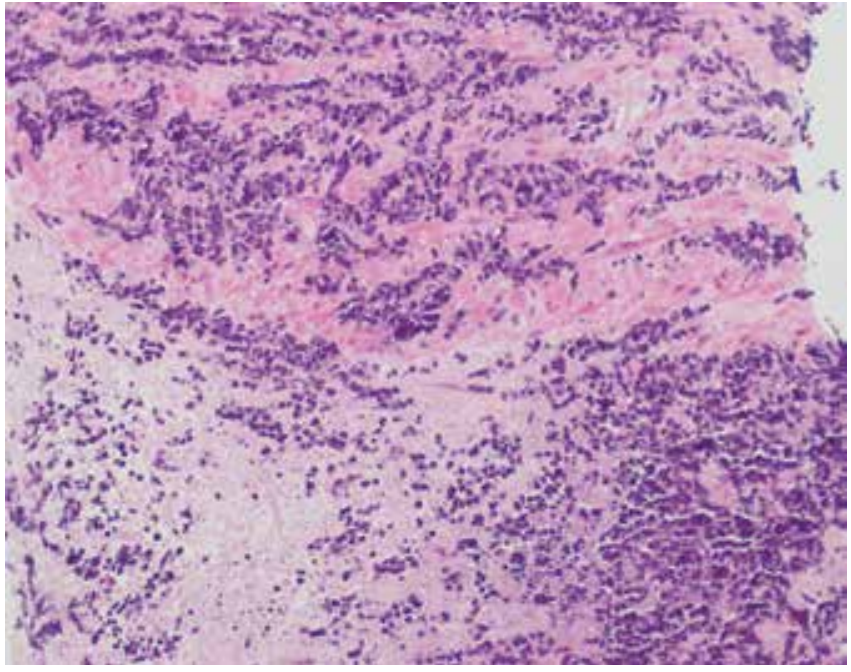

Figure 2. Core biopsy of the prostate: Hematoxylin and eosin stain with x100 magnification revealed small cell carcinoma cells forming diffuse solid sheets with infiltration of prostatic muscle fibers and narrow cords with some areas of necrosis. Tumor cells demonstrated mild to moderate pleomorphism with high nuclear to cytoplasmic ratio, crowded round to irregular nuclei containing chromatin. There was no acinus formation or any component of adenocarcinoma, urothelial carcinoma, squamous cell carcinoma or sarcomatoid carcinoma. Core biopsy of the left and right seminal vesicles demonstrated identical findings (not shown)

Recommended treatment regimens for urogenital small cell cancer are similar to those for small cell carcinoma of the lung. Chemotherapy is the mainstay of treatment, with radiation therapy being used either to enhance local control or for palliation of symptoms in metastatic disease (8). 18F-FDG PET imaging has been shown to be useful for staging small cell lung cancer but the rarity of urogenital small cell cancer has precluded a similar analysis (9). However, the demonstration of marked 18F-FDG uptake in primary small cell carcinoma of urogenital origin indicates that there may be a role for 18 F-FDG PET/CT scan in the staging and probable response assessment of EPSCC.

\section{Authorship Contributions}

Concept: Informed consent was obtained from the patient's relatives, Data Collection or Processing: Amir Iravani Tabrizipour, Chuong Bui, Analysis or Interpretation: Amir Iravani Tabrizipour, Literature Search: Amir Iravani Tabrizipour, Robert Mansberg, Writing: Amir Iravani Tabrizipour, Lily Shen, Robert Mansberg, Chuong Bui, Peerreview: Externally peer-reviewed, Conflict of Interest: No conflict of interest was declared by the authors, Financial Disclosure: The authors declared that this study has received no financial support.

\section{References}

1. Hindson DA, Knight LL, Ocker JM. Small cell carcinoma of the prostate. Transient complete remission with chemotherapy. Urology 1985;26:182-184.

2. Wang W, Epstein Jl. Small cell carcinoma of the prostate. A morphologic and immunohistochemical study of 95 cases. Am J Surg Pathol 2008;32:65-71.

3. Kim B, Kawashima A, Ryu JA, Takahashi N, Hartman RP, King BF Jr. Imaging of the seminal vesicle and vas deferens. Radiographics 2009;29:1105-1121.

4. Sala E, Akin O, Moskowitz CS, Eisenberg HF, Kuroiwa K, Ishill NM, Rajashanker B, Scardino PT, Hricak H. Endorectal MR imaging in the evaluation of seminal vesicle invasion: diagnostic accuracy and multivariate feature analysis. Radiology 2006;238:929-937.

5. Nicholson SA, Beasley MB, Brambilla E, Hasleton PS, Colby TV, Sheppard MN, Falk R, Travis WD. Small cell lung carcinoma (SCLC): a clinicopathologic study of 100 cases with surgical specimens. Am J Surg Pathol 2002;26:1184-1197.

6. Tetu B, Ro JY, Ayala AG, Johnson DE, Logothetis CJ, Ordonez NG. Small cell carcinoma of the prostate. Part I. A clinicopathologic study of 20 cases. Cancer 1987;59:1803-1809.

7. Bolton DM, Chiu ST, Clarke S, Angus D. Primary small cell carcinoma of the prostate: unusual modes of presentation. Aust N Z J Surg 1994;64:91-94.

8. Papandreou CN, Daliani DD, Thall PF, Tu SM, Wang X, Reyes A, Troncoso P, Logothetis CJ. Results of a phase II study with doxorubicin, etoposide, and cisplatin in patients with fully characterized small-cell carcinoma of the prostate. J Clin Oncol 2002;20:3072-3080.

9. Fischer BM, Mortensen J, Langer SW, Loft A, Berthelsen AK, Petersen $\mathrm{BI}$, Daugaard G, Lassen U, Hansen HH. A prospective study of PET/CT in initial staging of small-cell lung cancer: comparison with $\mathrm{CT}$, bone scintigraphy and bone marrow analysis. Ann Oncol 2007;18:338-345. 